\title{
VENOUS THROMBOEMBOLISM AND AIR TRAVEL
}

\section{Introduction}

There has recently been increased publicity on the risk of venous thromboembolism after long haul flights This was generated by the death of a 27 year old woman from a pulmonary embolism immediately after she disembarked from a flight from Australia to London' .

Venous thrombosis commonly develops in the deep veins of the leg or arm, or in the superficial veins of the extremities. Superficial venous thrombosis is a relatively benign disorder unless extension into the deep venous system develops. Thrombosis involving the deep veins of the leg is divided into two prognostic categories: 1) calf vein thrombosis in which thrombi remain confined to the deep calf vein, and 2) proximal vein thrombosis in which thrombosis involves the popliteal, femoral, or iliac veins. Pulmonary emboli originate from thrombi in the deep veins of the leg in $90 \%$ or more of the patients. Other less common sources of pulmonary embolism include the deep pelvic veins, renal veins, inferior vena cava, right side of the heart, or the axillary veins. Most clinically important pulmonary emboli arise from proximal deep vein thrombosis of the leg Deep vein thrombosis and/or pulmonary embolism are referred to collectively as venous thrombormbolism (VTE). In 1954 Homans" reported venous thromboembolism related 10 air travel in a 54 year old doctor who developed a cleep) vein thrombosis after a 14 hour flight. This condition was first termed economy class syndrome by Symington and Stack in 1977. Venous stasis, caused by prolonged sitting in the "coach" position in a cramped aircraft, was considered to be the main causal factor. Similar conditions to air travel, such as sitting for many hours in air raid shelters in London during the Blitz, were associated with a sixfold rise in sudden death from pulmonary embolism'. Subsequently, there have been many anecelotal cases of VTE apparently associated with long-distance airline travel, but it is only in the relatively receent

\section{by M. Simons, aeromedical surgeon}

past that more scientific assessment of the problem has been attempted.

Nevertheless, there is still disagreement among experts about whether a true association between VTE and air travel really exists. One of the issues has been the fact that the true incidence of in-flight and post-flight medical emergencies is unknown. It is probable that many such problems present to health professionals remote from the point of travel, perhaps even several weeks after the event. Often, the possible relevance of preceding travel to a particular ailment may not be appreciated or understood. Reliable data collection on VTE is further hindered by the fact that the clinical diagnosis of VTE is highly nonspecific.

This article describes epidemiology and pathophysiology of venous

thromboembolism and discusses possible relations with air travel.

Recommendations are made for further study of the problem and for prevention of VTE in travellers.

\section{Clinical features of venous thromboembolism}

The clinical implications of VTE are varied, depending on the anatomical site of the thrombosis and the extent of involvement of the leg and/or pelvic veins. Many minor episodes of thrombosis probably pass unnoticed and resolve spontaneously, but others prove to be progressive. Snall clots localised to the calf veins might cause temporary pain and swelling of the leg, but no other serious complication. As the popliteal, femoral and more proximal deep veins are involved by thrombosis, the main venous ontflow from the limb is progressively more obstructed, resulting in increasing signs and symptoms. In an extreme case, the leg is entirely dependent on the superficial veins for the venous return.
Although it occurs occasionally, it is unusual for clots originating in superficial veins, such as varicose veins, to extend into the deep veins with serious consequences.

The clinical diagnosis of VTE is highly nonspecific because each of the symptoms or signs may be caused by nonthrombotic disorders. The rare exception (less than $1 \%$ of the cases) is the patient with phlegmasia cerulea dolens, in whom the diagnosis of massive iliofemoral thrombosis is obvious. In most patients, the signs and symptoms are nonspecific, and in $50-85 \%$ of patients the clinical suspicion of VTE is not confirmed by objective testing $5, i_{i, i}$.

When a thrombus detaches from the wall or lumen of a vein and is carried through the circulation to lodge in the arterial tree of the lungs, pulmonary embolism (PE) has occurred. The segments of the lung associated with obstructed pulmonary arteries continue to be ventilated with air by the process of breathing, but because blood perfusion is obstructed, normal oxygen transfer cannot readily occur. If this phenomenon is significant, hypoxia follows, and is manifested as shortness of breath. Small emboli to the periphery of the lungs may cause chest pain and the coughing up of blood. However, it is thought that small pulmonary emboli can often be "silent", without causing any symptoms. As the volume of the inuacted clot increases, there is increasing resistance to flow through the pulmonary arteries, leading to dysfunction of the right ventricle of the heart. This can result in decreased cardiac output, shock, heart rhythm disturbances, collapse or cardiac arrest.

Causes of venous thromboembolism Venous thrombi are composed mainly of fibrin and erythrocytes, with variable

Aviation Medicini Group, TNO Human Factors Research Institute, Soesterberg. Artikel ontwangen februali 2002 
thrombocyte and leukocyte components. Their formation, growth, and breakdown reflect a balance between thrombogenic stimuli and protective mechanisms. The thrombogenic stimuli, known as Virchow's triad are:

- venous stasis;

- endothelial dysfunction/damage vessel wall;

- activated coagulation;

The protective mechanisms ${ }^{n}$ are:

- inactivation of activated coagulation factors by circulating inhibitors (e.g. antithrombin III, activated protein $\mathrm{C}$ ); clearance of activated coagulation factors and soluble fibrin polymer complexes by the reticulo-endothelial system and the liver;

- lysis of fibrin by fibrinolytic enzymes derived from plasma, endothelial cells, and leukocytes.

\section{Venous stasis}

The main drive for venous flow is the calf muscle pump with the venous tone controlling distribution and rate of return. The loss of the normal mechanisms for maintaining sufficient venous return will be manifest as a decrease in venous blood velocity. Ashby et al." have shown that for legs that are immobile, the blood flow within the lower leg veins is reliant on the position of the limb (table 1).The lowest blood velocity is in the sitting position with the lower legs in a vertical position.

position

Sitting with lower legs vertical

1.3

Standing upright

Lying horizontally

27.6

Table 1. Posilion legs and flour rerlocity in the wins (Ashby et al. 1995).

It is concluded that prolonged immobility, especially in the sitting position, results in a decrease in venous blood flow. However, a considerable decrement in flow or even the fact that there is no flow does not necessarily result in thrombosis. Ising isolated vein segments, Wessler ${ }^{\text {t" }}$

demonstrated that thrombi could not be visualised until 60 minutes after stasis. He reported microthrombi which consisted mainly of fibrin, and increased only slowly with time, such that coagulation was still not complete 8-10 hours after stasis. This observation suggests that while some degree of partial thrombosis can be generated by stasis alone, this does not lead to an accelerated process of largescale vein thrombosis. Post-mortem studies produced evidence that thrombi preferentially originate in the valve sinuses of the venous system. It has been suggested that turbulence within these valve pockets not only increase the risk of coagulation but also the preferential disposition of cellular components within the sinus". Whether these microthrombi will develop into clinically significant thrombi, depends on the balance between thrombus progression and fibrinolysis, which may be in part dependent on the continuing presence of leg immobility. Lack of blood flow will result in pooling within the veins, which is maximal after approx. 1 hour's. Initially the pressure in the veins remains relatively static. However, once fully distended any additional increase in volume results in an increase in intravenous pressure. This relationship becomes non-linear, and small increases in volume will result in a disproportionate increase in pressure. The increased pressure has a direct and proportional effect on the function of the endothelium (second factor in Virchow's triad). The endothelium plays an important role in fibrinolysis. There is evidence that exposure of the endothelium to unusually high pressure will result in endothelial damage ${ }^{1: 3}$.

\section{flow velocity $(\mathrm{cms} / \mathrm{sec})$}


thromboembolism. However, these conditions are rare. Far more common in the general population are genetic risk factors. These include activated protein (; resistance caused by a mutation in blood coagulation factor $V$, known as factor $V$ Leiden, which affects about $5 \%$ of the Caucasian population. An increased risk of thrombosis is also associated with a mutation of the prothrombin (factor II) gene, causing increased plasma concentrations of prothrombin $20210 \mathrm{~A}$ in $2 \%$ of the general population. In addition, high levels of factor VIII ( $11 \%$ prevalence), hyperhomocysteinaemia (5\% prevalence), and antiphospholipid antibody syndrome are now recognised as frequent causes of VTE.

In families or individuals with a history of repeated venous thrombosis, the prevalence of factor $V$ Leiden is extremely high. However, the fact that an individual may be affected by one of these genetic anomalies does not mean that they will inevitably suffer from a VTE. It will be the interaction of that particular risk factor with other genetic and environmental risk factors, during the course of their lifetime, which determines an adverse event. For example, a woman carrying factor $\mathrm{V}$ Leiden might have a hypothetical risk of thrombosis, but may not suffer any consequence until she takes the oral contraceptive, when the synergism between two risk factors results in a VTE.

\section{Incidence of venous thromboembolism}

Venous thromboembolism is a common disorder. The estimated anmual incidence of symptomatic thromboembolism is 117 cases per 100.000 population "t. This translates to more than 250.000 patients each year in the United States and to 18.000 patients in The Netherlands. The incidence of venous thromboembolism increases with each decade over the age of 40. This makes venous thromboembolism an increasingly important health problem in the Western World.

As in the year 2000, a total of 1647 million airline passengers were carried, travelling over a total of 3017790 million

kilometres ${ }^{1 i}$, it is not surprising that some passengers will develop thromboembolism during a flight, even if the effects of aircraft cabin factors would not play a role. Moreover, the number of in-flight thromboembolic events might further increase, because non-stop flights cover ever increasing distances and more and more aged and/or diseased persons are travelling, whereas age and illness are predisposing factors for venous thromboembolism.

\section{Studies on the association between VTE and air travel}

At present, the incidence of in-flight thromboembolism is not known because thus far only cases or series of cases have been reported in the literature. Scurr et al. ${ }^{18}$ tried to estimate the frequency of symptomless VTE in long-haul flights via a randomised trial. They found extremely high numbers ( 1 in 10) of passengers who developed symptomless VTE during travel. However, the results of this study are questioned on methodological grounds and are in contrast with the results of Ten Cate et al. "', who found no cases of VTE in 53 physicians flying non-stop from Amsterdan to Tokio. In this study I ${ }^{1.2}$ Fibrinogen i.v. was administered before the flight and a scan was made 24 hours after arrival.

Arfvidsson et al." studied 109 patients with VTE of which 25 had a history of recent travel (airborne 5-18 hrs). Twenty of these 25 patients reported symptoms within less 24 hrs after start of flight. $92 \%$ of the patients had one or more risk factor(s) for VTE, such as chronic disease or malignancy, obesity, recent surgery; injuries, and hormone therapy (table 2). In a recent case control study of 788 patients, Kraaijenhagen et al. ${ }^{21}$ (table 2) concluded that there was no increased risk of venous thrombosis among travellers. However only 4 VTE patients and 13 non-VTE controls gave a history of air travel. The results should be balanced by the findings of Ferrari et al.". (table 2), who showed in another case-control study that a history of recent travel was found almost four times more often in patients with deep vein thrombosis than in controls. In another study the coroner for the area including Heathrow airport in London reported 61 deaths in arriving passengers over three years. Eleven were due to pulmonary embolism. In the same period venous thromboembolism was attributable to only one of 28 deaths in those waiting to embark $\mathrm{m}^{* 3}$.

Lapostolle et al."-4 studied cases with pulmonary embolism (PE) on arrival at the airport and found that the PE risk increases with the distance travelled. The $\mathrm{PE}$ risk for passengers travelling less than $5000 \mathrm{~km}$ was estimated at $0.01 / 106$ while this risk was $4.8 / 106$ for those who travel more than $10.000 \mathrm{~km}$ (table 2). In a still ongoing Dutch case-control study preliminary analysis shows evidence for an increased VTE risk for all kinds of travel ( $>4 \mathrm{hr}$ ), with the highest risk for air travel. Moreover, the preliminary analysis shows that risk seems to multiply for subjects with a prothrombotic mutation who travel more than 4 hours by aircraft (F.R. Rosendaal, 2001 personal communication).

\begin{tabular}{|c|c|c|c|c|}
\hline authors & mothool & $N$ & findingss & moli \\
\hline Arfvidsson ef al. 104) & $\begin{array}{l}\text { case study } \\
\text { history of VTE } \\
\text { patients }\end{array}$ & 109 & $\begin{array}{l}25 \text { recently airbone (5-18 hrs) } \\
12 \% \geq 1 \text { risk factor }\end{array}$ & $\begin{array}{l}20 / 25 \text { had symptoms }<24 \\
\text { (5-18 hrs shrs after start of flight }\end{array}$ \\
\hline Ferrari et al. 1999 & $\begin{array}{l}\text { case control } \\
160 \text { VTE } \\
160 \text { no-VTE }\end{array}$ & 160 & $\begin{array}{l}\text { ()R for all travel } 3.488 \\
\text { (1).5\% (II: } 1.4-8.4)\end{array}$ & $\begin{array}{l}2-1,5 \% \text { of VTE pat. vs. } \\
7.5 \% \text { of no-VTE recently } \\
\text { made journey }>5.7 \mathrm{hr}\end{array}$ \\
\hline Kraajienhagen et al. 2000 & $\begin{array}{l}\text { case control } \\
186 \mathrm{VTE} \\
\text { (302 no-VTE }\end{array}$ & 788 & $\begin{array}{l}\text { ()R for air travel } 1.0 \\
(05 \% \text { ( I } 10.3-3-3.0)\end{array}$ & $\begin{array}{l}\text { only } 4 \text { VTE and } 13 \text { no-VTE } \\
\text { gave history of air } \\
\text { travel in past } 4 \text { weeks }\end{array}$ \\
\hline Lapostolle et al. 2001 & $\begin{array}{l}\text { case study } \\
\text { pax with Ple on } \\
\text { arrival at airport }\end{array}$ & 56 & $\begin{array}{l}\text { PE risk increases } \\
\text { with distance } \\
\text { laverlled }\end{array}$ & $\begin{array}{l}<5000 \mathrm{~km}: 0.01 / 10^{\circ} \\
>5000 \mathrm{km:}: 1.5 \text { (ases } / 10^{\circ} \\
>10.000) \mathrm{km}: 4.8 / 10^{\circ}\end{array}$ \\
\hline
\end{tabular}

Table D. Studies on possible relation venous thromboembolism (VTE) (and (air)trabel. Par=passengers; PE=pulmonary embolism; OR=odds ratio. 
Does air travel create extra risks for venous thromboembolism?

An important question is whether there are any contributory causes of venous thrombosis that might be designated "travel-related", or more particularly, "airline cabin-related". In the context of this question, it is useful to consider the possible effects of travel and the aircraft cabin environment on the three etiological factors postulated by Virchow: venous stasis, endothelial dysfunction, activated coagulation.

\section{Venous stasis}

Everyone who has travelled on long-haul routes has had the opportunity to observe the majority of passengers to remain immobilized during extended periods of time. Especially during night flights, passengers doze off and sleep in awkward positions, not being sufficiently conscious to follow airline's advices to exercise their calf muscles. Dozing off, awkward positions, and relaxation of the leg musculature is further favoured by ingestion of alcoholic beverages, which are offered for free in most cases, and hypnotics. Immobilization, particularly with the lower legs in vertical position, is a major contributory factor for VTE. Although, this type of immobilization can also be observed in other forms of transport, periods of immobilization tend to be longer in long-haul air travel, as in coach travel several sanitary or touristic stops are made along the route and in train travel seating is more spacious and there is a greater challenge to walk around. Development of thrombi may further be favoured by prolonged knee flexion and pressure of the edge of the seat on the femoral/popliteal vein, which may cause damage to the vessel wall.

\section{Endothelial dysfunction}

Hypoxia has shown to depress fibrinolytic properties of endothelial cells". A cabin altitude of $8000 \mathrm{ft}$ ( $2438 \mathrm{~m}$ ), which is equivalent to a cabin ambient pressure of $75.8 \mathrm{kPa}$, is considered to be the maximum acceptable cabin altitude of modern airliners cruising at altitudes up to 43.000 ft $(13.106 \mathrm{~m})$. Simons \& Krol ${ }^{25}$ have measured oxygen saturation of haemoglobin ( $\mathrm{SaO}_{2}$; ear pulse-oximetry) in resting healthy subjects seated in a hypobaric chamber with an inside ambient pressure of $75.8 \mathrm{kPa}$. Mean $\mathrm{SaO}_{2}$ was $90 \%$ $(\mathrm{SD} \pm 1.9$; range $85-93$ ) after $30 \mathrm{~min}$ of exposure. There is considerable inter- individual variation in the responses to a lowered partial O: pressure. Responses to hypoxic hypoxia include an increase in pulmonary ventilation, which can already be observed at $6600 \mathrm{ft}$. However, immobility, cramped seating conditions, and drowsiness, as occur in passengers on long-haul flights, might hinder proper respiratory activities. Moreover, the lower ambient pressure in the cabin leads to gastro-intestinal distension (relative expansion 1.4 at $75.8 \mathrm{kPa}$ ), which might. limit downward movements of the diaphragm. In subjects, who were dozing off in the hypobaric chamber, much lower $\mathrm{SaO}$ levels $(80 \%)$ at cabin altitudes of 8000 $\mathrm{ft}$ were found ${ }^{\prime \prime}$.

\section{Activated coagulation.}

Bendz et al."il found an increase in markers of activated coagulation in 20 healthy subjects seated for 8 hours in a hypobaric chamber where the pressure was $76 \mathrm{kPa}$ which is equivalent the cabin pressure in an airliner cruising at $40.000 \mathrm{ft}$. Since Simons \& Krol" ${ }^{2-3}$ suggested that the degree of hypoxia in aircraft passengers, who are sleeping or dozing in cramped positions may be more severe than observed by Bendz et al., the activating effects of hypobaric hypoxia on coagulation may be more pronounced than assumed thus far. Although they provide no evidence, many authors mention a possible thrombogenic effect of haemoconcentration caused by the dry cabin environment (relative humidity $10 \%$ in combination with insufficient fluids ingestion and the use of alcohol (which also has a dehydrating effect). Simons \& Krol": found some evidence for this suggestion, demonstrating systemic dehydration in healthy subjects who were allowed to drink $2 \mathrm{~L}$ of fluids in 8 hours in a hypobaric chamber at $75.8 \mathrm{kPa}$ pressure with a relative humidity of $10 \%$ (significant increase osmolality of blood and increase specific gravity of urine). However, airlines nowadays offer plenty of non(arbonated fluids and healthy subjects will feel thirsty before systemic dehydration will occur. Therefore, this finding may be of minor importance for healthy and sensible passengers (not replacing fluids by alcohol), although it may have conse(puences for diseased and/or aged passengers, who are already marginally hydrated before the start of their journey.

\section{Prevention of VTE during travel}

A number of preventive measures are recommended to airline (and other) travellers, to reduce the risk of venous thromboembolism, especially in journeys exceeding 4 hours duration. Unless there are significant pre-existing risk factors, it seems likely that attention to the following issues would markedly lower the risk to the average traveller.

- Leg exercises. Static leg exercises, to encourage the venous circulation and decrease venous stasis, can be performed easily while sitting in an airline seat. Exercise calf muscles whilst seated by half-hourly flexing and rotating of ankles for a few minutes. While regular walking might be better, this is unlikely to be practicable in a large airliner full of travellers.

- Regularly stretch upper part of body to optimise ventilation.

- Minimise alcohol intake. Drink adequate non-alcoholic and noncarbonated fluid.

- Avoid sedative/hypnotic medications.

- Take only short periods of sleep, unless horizontal sleeping position can be attained.

- Consider to wear compression stockings. Properly fitted below-knee compression stockings significantly decrease venous stasis in the legs, and will amplify the beneficial effect of leg exercises on the venous circulation.

- Avoid smoking.

For travellers with a pre-existing medical condition, or other known risk factor(s), additional drug prophylaxis might be justified, on an individual basis. Consultation with an appropriate specialist is necessary. Although commonly recommended, the use of aspirin as a preventative measure in this situation is controversial, and there is no specific evidence to indicate its efficacy in reducing the incidence of venous thromboembolism associated with air travel. While unlikely to be harmful in most people, even low-dose aspirin could have significant side effects in susceptible individuals, so caution with use is urged. Perhaps more importantly, overconfident reliance on the protective effect of aspirin may result in reduced application of the other simple prophylactic measures mentioned above.

For those at substantial risk (i.e. previous or current VTE, known clotting tendency, recent major surgery or stroke, current malignant disease or chemotherapy, paralysed lower limb):

- consider avoiding or postponing flight, 
taking medical advices il unsture;

- if travelling, follow all the above actvice and have low moleconlar weight heparin prescribed.

\section{Conclusion and recommendations}

Up to now, studies addressing a possible link between air travel and venous thromboembolism used different methodologies and produced conflicting results. These varied from no clear association to a strong relationship. The most recent epidemiological studiess evidenced that a link probably exists, affecting mainly passengers with additional risk factors for venous thromboembolism. Based on aeromedical and fundamental physiological literature, it is concluded that compared to other modes of transport, air travel carries some specific risk factors which may explain the higher risks for VTE found in some recent literature. These factors are prolonged immobilization in unfavourable positions, hypobaric hypoxia, and low relative humidity. An increase of cases is to be anticipated, as nowadays more aged and diseased passengers fly over ever increasing non-stop distances. It is recommended to adopt the recommendations of the WRIGIIT Protocol (WHO Research Initiative on Global Hazards of Travel), which were formulated at the wHO expert meeting in March 2001:

- A set of multicentre international epidemiological studies should be conducted including a large prospective colort study examining hard clinical end-points te answer the questions: Is there a link and if so what is the absolute risk? What is the size of the problem? Such a stuly will also provide clues to other aetiological faclors.

- Conduct speredal studiess seoking intermediate entl-points in groups of volunterss examining isolated independent envirommental and behavioural risk factors.

- Conduct an interventional study involving passengers prospectively using objoctive diagnostie mothords and examining various interventional modes.

Concerning the second WII) recommendation, aeromedical researeh should foress on studies into the pessiblo thrombogenice effects of the spereifice enviremmental facters encountered during flight, viz. hypobaric hypoxia, low relative humidity in combination with prolonged immobilization/ sleeping. In collaboration with experts on coagulation, such studies can be conducted in a hypobaric chamber, which allows for well controlled experimental conditions and practicable instrumentation.

\section{Summary VENOUS THROMBOEMBOLISM AND AIR TRAVEL}

Studies addressing a possible link between air travel and venous thromboembolism used different methodologies and produced conflicting results. The most recent epidemiological studies evidenced that a link probably exists, affecting mainly passengers with additional risk factors for venous thromboembolism. Based on aeromedical and fundamental physiological literature, it is concluded that compared to other modes of transport, air travel carries some specific risk factors which may explain the higher risks for VTE found in some recent literature. These factors are prolonged immobilization in unfavourable positions, hypobaric hypoxia, and low relative humidity. An increase of cases is to be anticipated, as nowadays ever more aged and diseased passengers fly over ever increasing non-stop distances.

It is recommended to adopt the recommendations of the WRIGHT Protocol (WHO Research Initiative on (ilobal Hazards of Travel):

- A set of multicentre international epideniological studies should be conducted including a large prospective cohort study examining hard clinical end points to answer the guestions: Is there a link and if so what is the absolute risk? What is the size of the problem? Such a study will also provide elues to other aetiological lactors.

- Comduct spereial studies seaking intermediate end points in groups of volunters examining isolated independent envirommental and behavioural risk factors.

- Conduct an interventional study involving passengers prospectively using objective diagnostic methods and examining various interventional modes.

Acromedical physiological research should focus on studies into the possible llurombogenic affects of the specific anvirommental factors encountered during flight, viz. hypobaric hypoxia, low relative humidity in combination with prolonged immobilization/sleeping. In collaboration with experts on coagulation, such studies can be conducted in a hypobaric chamber, which allows for well controlled experimental conditions and practicable instrumentation.

\section{Samenvatting DIEPE VENEUZE TROMBOSE EN VLIEGREIZEN}

Studies naar een mogelijk verband tussen diepe veneuze trombose (DVT) en het reizen per vliegtuig vertonen grote verschillen, zowel in de gebruikte onderzoeksmethoden als in de uitkomsten. De meest recente epidemiologische studies leveren aanwijzingen dat lange vliegreizen mogelijk een verhoogd risico op DVT met zich brengen, vooral voor passagiers die predisponerende factoren voor DVT hebben. Gebaseerd op luchtvaartmedische en fysiologische kennis, wordt geconcludeerd dat in het vliegtuig enkele specifieke risicofactoren een rol spelen, die een hoger risico voor DVT kunnen verklaren. Deze specifieke risicofactoren zijn: langdurige immobilisatie in ongunstige lichaamshoudingen, hypobare hypoxie en lage relatieve luchtvochtigheid. Het is te verwachten dat het aantal gevallen van DVT bij vliegreizen zal toenemen, omdat tegenwoordig steeds meer oudere en/of chronisch zieke passagiers steeds langere non-stop reizen ondermemen.

Er zal nog veel onderzoek moeten gebeuren om duidelijk te krijgen hoeveel groter het risico is, welke causale factoren precies een rol spelen en welke profylactische maatregelen het meest effectief zijn. Dergelijk onderzoek zou gecoördineerd plaats moeten vinden volgens de aanbevelingen van de Wereldgezondheidsorganisatie (WHO Research Initiative on Global Hazards of Travel).

Luchtvaartgeneeskundig fysiologisch onderzoek moet zich vooral concentreren op studies naar de mogelijk thrombogene effecten van de specifieke factoren die een rol spelen in het vliegtuig. In samenwerking met stollingsdeskundigen kan dergelijk onderzoek worden uitgevoerd in een hypobare kamer, waarin men de experimentele condities goed kan controleren en men uitgebreider metingen kan uitvoeren dan in een vliegtuig. 
References:

1. Perry K.: Blood clot kills woman after flight. Guardian 2001; $230 \mathrm{Oct}, 2001$.

2. Homans J.: (1954). Thrombosis of the deep leg veins due to prolonged sitting. $N$ Engl $J$ Med 1954; 250: 148-149.

3. Symington I.S., Stack B,H.R.: Pulmonary hromboembolism after travel. Br J Chest 1977; 17: 138-140

4. Simpson K.: Shelter deaths from pulmonary embolism. Lancet 1940; 11:744.

5. Birdwell B.G., Raskob G.E., Whitsett T.L. et al.: The clinical validity of nomal compression ultrasonography in outpatients suspected of having deep venous thrombosis. Ann Intern Med 1998; 128(1):1-7.

6. Hull R.D., Hirsh J., Carter C.J., et al.: Diagnostic efficacy of impedance plethysmography for clinically suspected deep-vein thrombosis. Ann Intern Med 1985; $102(1): 21-28$.

7. Hull R.D., Carter C.J., Jay R.M., et al.: The diagnosis of acute, recurrent deep vein hrombosis: a diagnostic challenge. Circulation 1983; 67(4):901-906.

8. Raskob G.E., Hull R.D., Pineo G.F.: Venous thrombosis. In: E. Beutler et al. (Eds). Williams Hematology, 6th edition. Mc GrawHill Medical Publishing, New York, 2001. p. 1735-1741.

9. Ashby E.C., Ashford N.S., Campbell M.J.: Posture, blood velocity in common femoral vein, and prophylaxis of venous

thromboembolism. Lancet 1995; 345:419-421.

10. Wessler S.: Thrombosis in the presence of vascular slasis. Am. J. of Med. 1962; 33:648606.

11. Sevitt S.: The structure and growth of valve pocket thrombi in femoral veins. J Clin Pathol. $1974 ; 27(7): 517-528$.

12. Shvartz E., Gaume J.G., White R.T., et al. Hemodynamic responses during prolonged sitting. J Appl Physiol 1983; 54:1673-1680.

13. Pandolfi M., Nilsson I.M., Robertson B. Isacson S.: Fibrinolytic activity of human veins. Luancet $1967 ; 2(7507): 127-128$.

14. Gertler J.P., Perry L., L'Italien G., Chung Welch N., Cambria R., Orkin R., et al.: Ambient oxygen tension modulates endothelial fibrinolysis. J Vasc Surg 1993; 18: $939-946$.

15. Schmitt H.E., , Mihahatsch M.J.: Thrombosis of the popliteal vein. Cardiovasc. Intervent. Radiol. 1992; 15(4):234-239.

16. Silverstein M.D., Heit J.A., Mohr D.N Petterson T.M., O'Fallon W.M., Melton L.J.: Trends in the incidence of deep venous thrombosis and pulmonary embolism. A 25year population-based study. Arch Intern Med $1998 ; 158: 585$.

17. ICAO: Annual Civil Aviation Report 2000 ICAO Journal 2001; 56(6):10-30

18. Scurr J.H., Machin S.J., Bailey-King S. et al.: Frequency and prevention of symptomless deep vein thrombosis in long-haul flights: a randomised trial. Lancet 2001; 357:1485-1489.

19. Ten Cate J.W., Büller H.R., van Royen $\mathbf{E}$ et al.: Incidence of deep venous thrombosis (DVT) during long non-stop air flights. Paper presented at the Aerospace Medica Association Scientific Meeting, New Orleans,
1990 - abstract 221

20. Arfvidsson B , Elof B, Kistner R.L., et al.: Risk factors for venous thromboembolism following prolonged air travel. Coach Class Thrombosis. Hematol. Oncol. Clin. North Am. $2000 ; 14: 391-400$

21. Kraaijenhagen R., Haverkamp D. Koopman M.M.W., Prandoni P., Piovella F., Buller H.R.: Travel and risk of venous thrombosis. Lancet 2000; 356: 1492-1493.

22. Ferrari E., Chevallier T., Chapelier A. Baudouy M.: Travel as a risk factor for venous thromboembolic disease: a case control study. Chest 1999; 115; 440-444.

23. Sarvesvaran R.: Sudden natural deaths associated with commercial air travel. Med Sci Law 1986; 26: 35-38.

24. Lapostolle F., Surget V., Borron S.W. Desmazières M., Sordelet D., Lapandry C., Cupa M., Adnet F.: Severe pulmonary embolism associated with air travel. $N$ Engl J Med 2001; 345:779-783.

25. Simons R, Krol J. Jet leg, pulmonary embolism, and hypoxia. Lancet 1996; 348:416.

26. Bendz B. Rostrup M. Sevre K., Andersen T.O., Sandset P.M.: Association between acute hypobaric hypoxia and activation of coagulation in human beings. Lancet 2000; 356: $1657-1658$

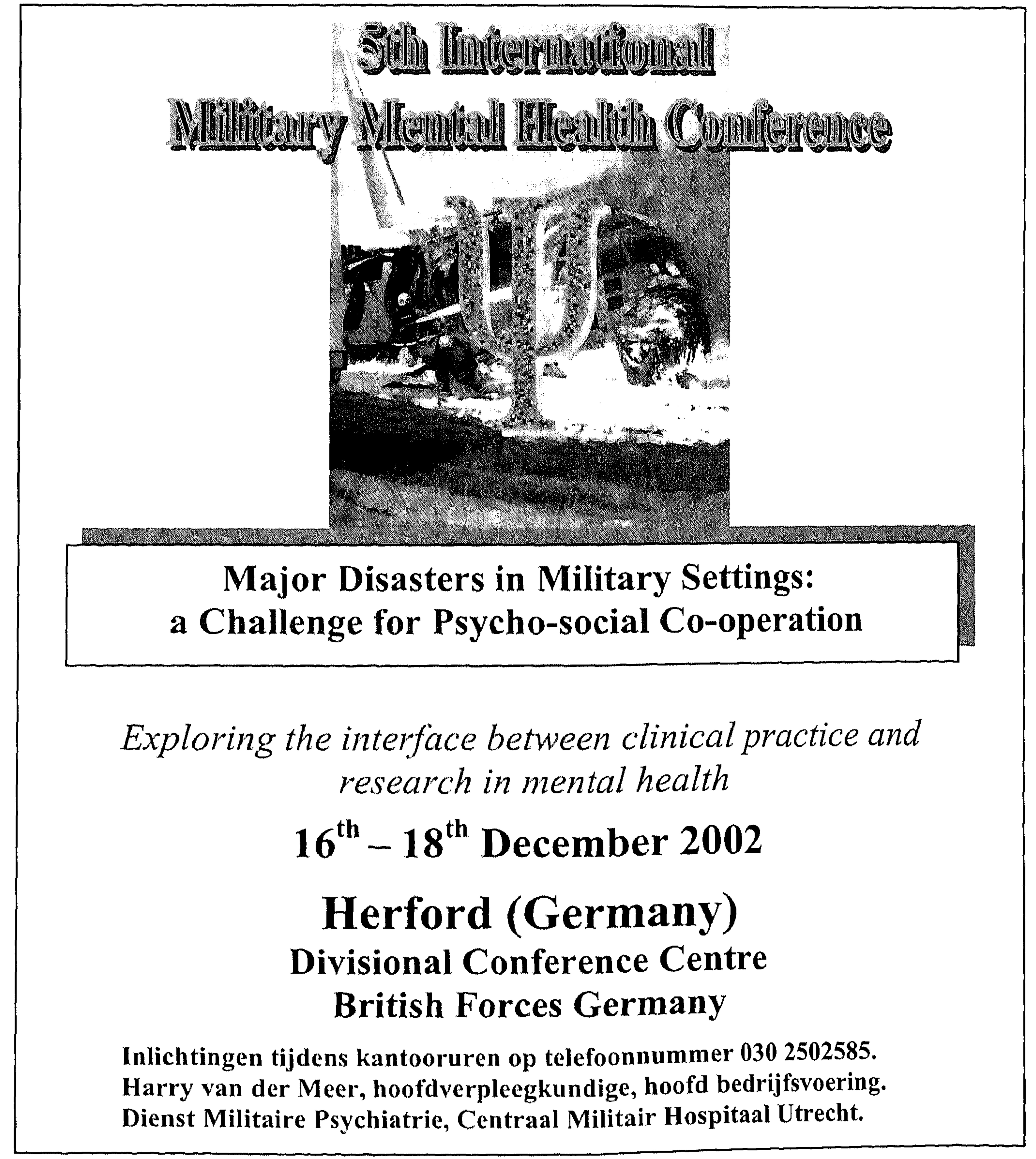

